
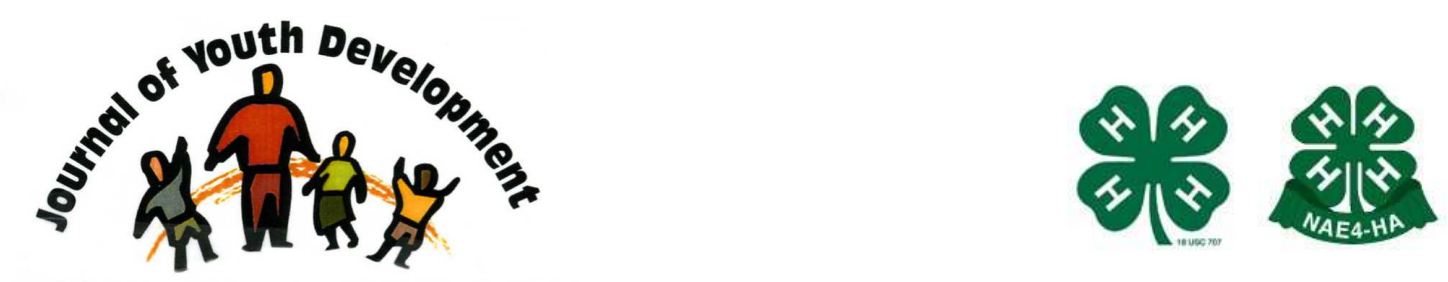

Bridging Research \& Practice

\title{
Neighborhood Youth Centers and Families as Supportive Environments for Youth in High Risk Urban Settings
}

\author{
Ronald M. Sabatelli \\ University of Connecticut \\ Storrs, CT \\ Ronald.sabatelli@uconn.edu
}

Stephen A. Anderson University of Connecticut Storrs, CT

Preston A. Britner University of Connecticut Storrs, CT

Julie A. Liefeld

Mitchell College 


\title{
JOURNAL OF YOUTH DEVELOPMENT \\ bridging research and practice

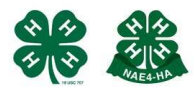

Volume 4, Number 3, Fall 2009

Article 090403FA005

\section{Neighborhood Youth Centers and Families as Supportive Environments for Youth in High Risk Urban Settings}

\author{
Ronald M. Sabatelli, Stephen A. Anderson and Preston A. Britner \\ University of Connecticut
}

Julie A. Liefeld

Mitchell College

\begin{abstract}
Highlights of a study which examined the relationship between contextual assets within the lives of urban, poor, minority youth, and youth adjustment are discussed in this article. The assets studied were family support and supportive involvement in neighborhood youth centers. The results indicated that higher levels of family support and youth center involvement were associated with better youth outcomes. An absence of significant interaction effects indicated that strong involvement and support in one setting did not compensate for a low level of support or involvement in the other setting. Family support was found to be the most significant predictor of youth adjustment.
\end{abstract}

\section{Introduction}

The goal of positive youth development (PYD) programs is to foster the development of resilience, social skills, and competencies that can facilitate young peoples' transition from adolescence into adulthood in healthy, pro-social ways (Roth \& Brooks Gunn, 1993). PYD models focus on fostering the development of positive adjustment by pairing youth's innate capabilities with structured supports and opportunities. Supports and opportunities include family, neighborhoods, schools, congregations, youth organizations, and community-centered programs (Benson, 2002; Connell, Gambone, \& Smith, 2000; Eccles \& Gootman, 2002). It is generally recognized that the greater the number of opportunities available to youth, the greater the likelihood they will develop in pro-social ways (Benson, 2002; Eccles \& Gootman, 2002). Successful youth development programs have been found to share several important characteristics. These include a safe setting, supportive relationships, challenging activities, and 
meaningful youth engagement (Walker, Marczak, Blyth, \& Borden, 2005; Yohalem, Pittman, \& Wilson-Ahlstrom, 2004).

Although successful youth programs offer opportunities to engage youth in stimulating and engaging activities, it is apparent that stimulating activities alone do not promote youth development. Meaningful involvement, and positive, supportive interactions with others are also essential elements (Larson, 2000; Rhodes, 2004). A study by the National Research Council (Eccles \& Gootman, 2002) identified supportive relationships, support for self efficacy, and support for mattering as essential elements of successful PYD programs. The importance of supportive staff relationships has been supported in a number of studies and forums (Halpern, 2005; Hirsch, Roffman, Deutsch, Flynn, \& Pagano, 2000; Noam \& Fiore, 2004; Rhodes, 2004). Among the 5 C's of PYD elaborated by Lerner and colleagues are a sense of connection and caring/compassion (Lerner et al., 2000; Lerner et al., 2005). These studies all point to the importance of attending not only to the types of opportunities or developmental settings available to youth but also to the quality of interpersonal relationships (e.g., support, caring, connection) that are offered within these settings and the level of involvement youth attain.

The present study examined family factors and youth center involvement as related to positive youth development. First, we were interested in whether positive relationships with family and neighborhood youth centers were independently associated with young people's adjustment. Second, we were interested in determining which of these two supportive contexts was most predictive of youth adjustment. Specifically, is an emotional connection to one or both settings most predictive of youth adjustment? If both settings predict positive adjustment, is one a more significant predictor than the other?

In the next sections, we provide further justification for importance of studying these two developmental settings in relation to one another.

\section{Family Dynamics and Positive Youth Development}

Two important family functions related to positive youth adjustment are parental monitoring and supportive family relationships. Parents who regularly monitor (i.e., are involved, knowledgeable about) their children's whereabouts, peer relationships, and out-of-home activities have been found to have better adjusted children in terms of levels of empathy and conflict management skills (Field, Diego, \& Sanders, 2002). Knowing where your child is and who he/she is with have been found to deter negative outcomes such as delinquency, aggression, depressive symptoms, and substance abuse (Ary, Duncan, Duncan, \& Hops, 1999; Parker \& Benson, 2004; Svensson, 2000). These same factors have been found to enhance positive skills such as ability to control anger and deal with frustration (Griffin, Scheier, Botvin, Diaz, \& Miller, 1999; Larson, 2000; Pabon, 1998; Smith \& Krohn, 1995).

Parental support has been shown to help insulate youth, including inner-city minority youth like the ones studied here, from anxiety and depression (Zimmerman, Ramirez-Valles, Zapert, \& Maton, 2000), foster self-esteem (McCreary, Slavin, \& Berry, 1996), and buffer the effects of stress and promote psychosocial adjustment (Taylor, 1996). Rohner and Britner (2002) maintain that parental acceptance and support are universal processes necessary to promote development and adjustment. Larson (2000) found that presence of family support increased the likelihood that youth would maintain their participation in youth program activities and thus increase the likelihood of receiving benefit. Youth who report a positive level of support within their families are also likely to hold more positive opinions of their community and to participate 
more in local youth programs thereby increasing the likelihood of benefit (Morrissey \& WernerWilson, 2005).

\section{Neighborhood Youth Programs and Positive Youth Development}

Research has suggested that minority youth living in inner city neighborhoods may be especially vulnerable to a host of social and mental health risks. Poverty, pervasive violence, and inadequate schools have been linked to higher rates of internalizing and externalizing behaviors for urban, minority youth (Hay, Fortson, Hollist, Altheimer, \& Schaible, 2007; Ingoldsby et al., 2006; Lerner et al., 2005; Li, Nussbaum, \& Richards, 2007; Prelow, Weaver, \& Swenson, 2006). Involvement in neighborhood youth centers have been found to offer youth a source of "primary support" or a "buffer" from environmental risks (Catalano, Berglund, \& Ryan, 2002; Morrissey \& Werner-Wilson, 2005; Werner \& Smith, 2001; Wynne, 1997). Neighborhood centers provide youth with alternative or "neutralizing" experiences and reduce exposure to negative experiences (Catalano et al., 2002; Masten, 2001; Werner \& Smith, 2001). Connections with centers offer youth a unique form of support that differs from their homes or schools.

Hirsch and his colleagues (c.f., Hirsch, 2005; Hirsch et al., 2000; Loder \& Hirsch, 2003; Roffman, Pagano, \& Hirsch, 2001) found that supportive and positive connections with youth centers were associated with improved self-esteem, psychosocial functioning, and greater likelihood of staying out of trouble. Positive involvement in youth centers also has been found to reduce aggression and internalizing problems such as anxiety or depression (Scales et al., 2000). According to Lerner (2004), sustained relationships with mentors or caring adults, with a focus on positive development and community involvement are critical components of community programs. Hirsch et al. (2000) found that neighborhood center staff provided a support function that fell between family support and the direct instruction received in their relationships with teachers.

The relationships between supportive families and involvement in supportive youth center relationships are not well understood. The studies reviewed above suggest that families and neighborhood youth centers are both directly related to positive youth outcomes. However, several authors reported that family support was not directly connected to positive youth outcomes. Rather, family support was connected to center use which in turn was associated with positive youth outcomes (Larson, 2000; Morrissey \& Werner-Wilson, 2005). The present study attempted to clarify these inconsistent findings by examining the direct effects of family support and youth center involvement on youth adjustment.

\section{Research Questions}

The following research questions were examined in this study of urban, minority youth living within impoverished neighborhoods.

1. Are levels of emotional involvement and support from family and connections to the neighborhood youth centers independently associated with adolescent adjustment?

A corollary of this question explores whether or not emotional support and involvement in one setting is more predictive of youth adjustment than emotional involvement and support in the other setting?

2. In what ways do family connections and center involvement work in conjunction with and independent of one another to predict youth adjustment?

It was expected that this sample of youth would reflect levels of adjustment consistent with the risk-laden environments in which they lived. Thus, the greater the number of supports and opportunities available to youth, the greater the likelihood they would report positive 
adjustment. It was expected that family supports, in particular, would be predictive of youth adjustment. What remains uncertain, however, is whether or not center involvement would be predictive of adjustment and whether or not center involvement would compensate in positive ways for the absence of family supports.

\section{Method}

\section{Study Design}

The data for this study were part of an evaluation of a state-wide "neighborhood youth center project." Twenty five youth centers in the state's largest and poorest cities were provided state funding to "increase the range and extent of positive experiences for at risk youth." The centers provide inner city youth with safe accessible spaces that provide supervised out-of-school activities. Centers were required to structure their programming around positive youth development principles with the goal of promoting development of skills and competencies that would enable youth to make positive choices and demonstrate improved resistance skills (Catalano et al., 2002; Masten, 2001; Werner \& Smith, 2001). More specifically, all centers involved in this study were required to offer: athletic and recreational opportunities; enrichment or tutoring activities; skills training in areas such as problem-solving, decision-making, conflict resolution, peer counseling and life skills; parent involvement in planning the program; youth involvement, including, but not limited to, input into planning and management of the program and youth leadership development activities; and, coordination with existing community services for youth.

Youth filled out one-time survey questionnaires during the fall of 2000, detailing their experiences within the centers and their relationships with their families along with several indicators of adolescent adjustment. The total number of surveys completed was 1360 . However, 305 surveys were removed because of incomplete data or because the age of the youth responding to the survey was under 12 or over 18 years of age. In addition, it was decided to drop the relatively small portion of the sample of youth whose ethnicity was White or "Other" (comprising 3\% of the total sample). These youth were dropped from the sample because their low numbers made it impractical to examine subgroup comparisons based upon ethnicity. As a result of these adjustments, the total sample used in the analyses consisted of 1055 youth.

This sample was comprised of 655 African American youth and 400 Hispanic youth. The mean age of the sample was 15.5 ( $S D=2.19$ ) years, with 54 and 45 percent of the sample, respectively, being males and females. Forty-five percent of this sample reported a " $\mathrm{B}$ " average in school, $12 \%$ reported an " $\mathrm{A}$ " average, and $25 \%$ reported a " $\mathrm{C}$ " average. The family status of the youth who participated in the study was quite varied. Forty-two percent of the sample resided with both their biological mother and father. Another $41 \%$ of the participants lived in a mother-headed household, and an additional $8 \%$ lived with relatives other than their biological parents. The remaining small percentage of participants reported living with other non-related adults. The information provided on the family income levels of the youth within the sample was not reliable. However, one reliable indicator revealed that slightly over $67 \%$ of the youth within the sample reported receiving free or reduced price meals at school, meaning they met the state poverty guideline for food assistance.

\section{Measures}

The variables included in this study focused on family and youth center connection and were measured by the following scales. 
Family support. The family support subscale was taken from the Multidimensional Scale of Perceived Social Support (MSPSS)-Family (Canty-Mitchell \& Zimet, 2000). It consists of 4 items to measure family support. The scale's dimensionality and psychometric properties have been affirmed in numerous studies (c.f., Dahlem, Zimet, \& Walker, 1991). The alpha reliability coefficient in the present study was .89 .

Parental monitoring. The scale used to assess family monitoring was developed by Voydanoff and Donnelly (1999). The scale consisted of 2 items, asking how often caregiver know who youth are with and what they are doing when they are away from home. The alpha reliability coefficient in the present study was .76 .

Youth involvement with the centers. Each youth's degree of involvement with the neighborhood centers was assessed with three measures. The amount of social support received from the staff at the centers was assessed with the Canty-Mitchell and Zimet (2000) Perceived Social Support Scale. The 4-item Significant Other Adult subscale was modified slightly to refer to relationships with center staff rather than adults in general. The alpha reliability was .90 .

Measures of "center use" and "center fit" were created for this study to assess the quality of the youth's experience within their centers. It was important to determine how much youth used their center. Center use was assessed by determining how frequently youth participated in four common activities: Athletics; Support with School Work; Skills Training (e.g., peer mentoring, leadership training, community service, computer or tech training); and, Other Social and Special Activities sponsored by the centers. The responses to these questions were summed to create a score representing center use. The alpha reliability of this scale of survey items was .72 .

The concept of "fit" follows the work of Hirsh et al. (2000), who found that young persons' satisfaction with their centers was associated with positive developmental outcomes. Thus, youth in the present study were asked to report on their happiness/satisfaction with various aspects of the centers (e.g., staff, types of programs offered, etc.). The term "center fit" was used to connote the degree of congruence between what youth were looking for at the centers and what they believed was being provided to them. A good match between youth needs and the types of experiences provided by the centers is thought to be necessary in order to facilitate positive developmental outcomes. The alpha reliability for this combination of survey items was .89 .

Adjustment variables: Youth internalizing and externalizing behaviors. Each youth's psychosocial adjustment was measured with three well established subscales of the Youth Self Report (YSR) instrument (Achenbach, 1991): anxiety, aggression, and delinquency. The YSR has been used to measure youth adjustment in over 4000 studies (Achenbach, 1991).

The anxiety subscale was used to assess the degree to which youth internalized their problems. The scale consists of 16 items, and the alpha reliability coefficient for this scale in the current study was .88. The two subscales included to measure externalizing problem behaviors were aggression (19 items) and delinquency (11 items), and their alpha reliability coefficients in this study were .89 and .79 , respectively. Higher scores on these measures were indicative of poorer levels of adjustment. 
These three measures were moderately to highly correlated with one another ( $r$ 's ranged from .58 to .76). Because of the high correlation between the measure of delinquency and aggression $(r=.76 ; p<.001)$, it was decided to combine these two measures into one indicator of Externalizing Problem Behaviors. Thus, two adjustment measures were used in the study. The first was a measure of Internalizing Problems Behaviors, as measured by the anxiety subscale of the YSR. The second was a measure of Externalizing Problem Behaviors, assessed by a combination of the aggression and delinquency scales of the Youth Self Report instrument.

Although the YSR is not a standard measure of PYD, it does measure psychosocial outcomes associated with positive development. These outcomes reflect one's ability to successfully cope with life in a high stress environment. In fact, numerous researchers have noted PYD is inversely related to risk behaviors such as aggression, as well as internalized problems such as depression or anxiety (c.f., Dryfoos, 1990; Lerner, 2004; Lerner et al., 2005; Perkins \& Borden, 2003; Scales et al., 2000).

\section{Results}

\section{Preliminary Analyses}

The correlations among the variables used in the study, along with their means and standard deviations, are reported in Table 1 . One point of interest is that youth scores on the internalizing and externalizing measures are consistent with national norms. The national mean for the internalizing indicator is 5.1 as compared to a mean of 5.7 in this sample. The national mean for the externalizing measure used in the study is 11.7 as compared to the sample mean of 12.0 (Achenbach, 1991).

Table 1

Intercorrelations of Independent (Family, Program) and Dependent (Youth Adjustment) Variables

\begin{tabular}{|l|l|l|l|l|l|l|l|}
\hline & 1 & 2 & 3 & 4 & 5 & 6 & 7 \\
\hline 1. Family Support & -- & & & & & & \\
\hline 2. Family Monitoring & $.32^{* *}$ & -- & & & & & \\
\hline 3. Staff Support & $.35^{* *}$ & .14 & -- & & & & \\
\hline 4. Program Use & -.01 & -.05 & $-.15^{* *}$ & -- & & & \\
\hline 5. Program Fit & .04 & .009 & $.06^{*}$ & $.05^{*}$ & -- & & \\
\hline 6. Internalizing & $-.24^{* *}$ & $-.11^{* *}$ & -.04 & -.05 & .03 & -- & \\
\hline \begin{tabular}{l} 
7. Externalizing \\
\multicolumn{1}{|c|}{$\mathrm{N}$}
\end{tabular} & $-.26^{* *}$ & $-.24^{* *}$ & $-.13^{* *}$ & -.03 & .00 & .66 & - \\
\hline 1055 & 989 & 1055 & 1055 & 1055 & 1055 & 1055 \\
\hline $\begin{array}{c}\text { Means and Standard } \\
\text { Deviations }\end{array}$ & $\begin{array}{c}5.4 \\
(1.7)\end{array}$ & $\begin{array}{c}3.9 \\
(1.1)\end{array}$ & $\begin{array}{c}4.8 \\
(1.9)\end{array}$ & $\begin{array}{c}2.3 \\
(1.3)\end{array}$ & $\begin{array}{c}3.1 \\
(0.8)\end{array}$ & $\begin{array}{c}5.4 \\
(3.3)\end{array}$ & $\begin{array}{c}12.0 \\
(4.6)\end{array}$ \\
\hline
\end{tabular}

Note: ${ }^{*} p<.05,{ }^{* *} p<.01, * * * p<.001$

Another important point is that the family variables are correlated in expected ways with the indicators of adjustment. That is, higher levels of family support and parental monitoring are associated with lower internalizing and externalizing scores. Center staff support was significantly correlated only with lower scores on the externalizing indicator. 
The approach to subsequent data analyses was determined, in part, by first examining whether adjustment scores differed according to participants' gender, race, family living arrangements, and age. Age was not significantly correlated with either of the adjustment indicators. Both gender and race differences were significant on the internalizing measure. Females $(M=6.2)$ scored significantly higher than males $(M=5.4)$ on the internalizing measure $(t=2.07$; $p<.03)$. Hispanics $(M=6.7)$, scored significantly higher than African Americans $(M=5.2)$ on the internalizing subscale as well $(\mathrm{t}=4.49 ; p<.001)$.

The only significant difference on the externalizing measure was with family living arrangements. Youth residing with both biological parents $(M=10.8)$ scored consistently lower on the externalizing scale $(\mathrm{F}=4.80 ; p<.003)$ than youth residing in other family types (singleparent family: $M=12.9$; remarried family: $M=13.2$; other living arrangements: $M=14.2$ ).

\section{Research Question 1: Do Supportive Relationships in Both Settings Independently Predict Youth Adjustment?}

Another important point is that the family variables are correlated in expected ways with the indicators of adjustment. That is, higher levels of family support and parental monitoring are associated with lower internalizing and externalizing scores. Center staff support was significantly correlated only with lower scores on the externalizing indicator.

The approach to subsequent data analyses was determined, in part, by first examining whether adjustment scores differed according to participants' gender, race, family living arrangements, and age. Age was not significantly correlated with either of the adjustment indicators. Both gender and race differences were significant on the internalizing measure. Females $(M=6.2)$ scored significantly higher than males $(M=5.4)$ on the internalizing measure $(t=2.07 ; p<$ $.03)$. Hispanics $(M=6.7)$, scored significantly higher than African Americans $(M=5.2)$ on the internalizing subscale as well $(\mathrm{t}=4.49 ; p<.001)$.

The only significant difference on the externalizing measure was with family living arrangements. Youth residing with both biological parents $(M=10.8)$ scored consistently lower on the externalizing scale $(F=4.80 ; p<.003)$ than youth residing in other family types (singleparent family: $M=12.9$; remarried family: $M=13.2$; other living arrangements: $M=14.2$ ).

Internalizing problem behaviors. The regression results for the internalizing measure are summarized in Table 2. The combination of covariates and predictors accounted for $10.1 \%$ of the variance $(F(7,912)=14.6 ; p<.001)$. Both gender and race emerged as significant predictors. Beyond these covariates, the family support and program use measures emerged as significant predictors. The examination of the Beta's suggests that family support is a considerably stronger predictor when compared to Program Use. 


\section{Table 2}

Summary of the Regression Analyses for Variables Predicting Internalizing Problem Behaviors

\begin{tabular}{|c|c|c|c|c|c|c|}
\hline \multirow[b]{2}{*}{ Model } & \multirow[b]{2}{*}{ Variables } & \multicolumn{2}{|c|}{$\begin{array}{c}\text { Unstandardized } \\
\text { Coefficients }\end{array}$} & \multirow{2}{*}{$\begin{array}{c}\text { Standardized } \\
\text { Coefficients } \\
\text { Beta } \\
\end{array}$} & \multirow[b]{2}{*}{$\mathrm{t}$} & \multirow[b]{2}{*}{ Sig. } \\
\hline & & B & Std. Error & & & \\
\hline \multirow[t]{3}{*}{1} & (Constant) & .195 & .036 & & 5.458 & .000 \\
\hline & Gender & .043 & .023 & .062 & 1.894 & .058 \\
\hline & Race & .106 & .023 & .151 & 4.629 & .000 \\
\hline \multirow[t]{8}{*}{2} & (Constant) & .599 & .074 & & 8.077 & .000 \\
\hline & Gender & .057 & .022 & .082 & 2.585 & .010 \\
\hline & Race & .087 & .022 & .124 & 3.889 & .000 \\
\hline & $\begin{array}{l}\text { Family } \\
\text { support }\end{array}$ & -.051 & .007 & -.256 & -7.201 & .000 \\
\hline & Monitoring & -.014 & .011 & -.045 & -1.353 & .177 \\
\hline & Staff Support & .005 & .006 & .026 & .755 & .451 \\
\hline & Program Fit & -.006 & .011 & -.017 & -.550 & .582 \\
\hline & Program Use & -.023 & .009 & -.082 & -2.543 & .011 \\
\hline
\end{tabular}

Externalizing problem behaviors. The regression results of the externalizing measure are summarized in Table 3. The combination of covariates and predictors accounted for $12.9 \%$ of the variance $(F(6,889)=21.8 ; p<.001)$. As expected, family living arrangements emerged as a significant predictor. Beyond this covariate, both indicators of family connections emerged as significant predictors. Youth who experienced higher levels of family support and monitoring scored lower on the scales assessing aggression and delinquent behaviors. Only one of the variables used to assess youth center involvement emerged as a significant predictor. This was program fit. Youth who reported greater satisfaction and happiness with the programs they attended were more likely to report lower levels of externalizing problem behaviors.

Table 3

Summary of the Regression Analyses for Variables Predicting Externalizing Problem Behaviors

\begin{tabular}{|c|c|c|c|c|c|c|}
\hline \multirow[b]{2}{*}{ Model } & \multirow[b]{2}{*}{ Variables } & \multicolumn{2}{|c|}{$\begin{array}{c}\text { Unstandardized } \\
\text { Coefficients }\end{array}$} & \multirow{2}{*}{$\begin{array}{c}\begin{array}{c}\text { Standardized } \\
\text { Coefficients }\end{array} \\
\text { Beta } \\
\end{array}$} & \multirow[b]{2}{*}{$\mathrm{t}$} & \multirow[b]{2}{*}{ Sig. } \\
\hline & & B & Std. Error & & & \\
\hline \multirow[t]{2}{*}{1} & (Constant) & .365 & .016 & & 22.712 & .000 \\
\hline & $\begin{array}{l}\text { Family } \\
\text { Structure }\end{array}$ & .036 & .011 & .106 & 3.174 & .002 \\
\hline \multirow[t]{7}{*}{2} & (Constant) & .930 & .062 & & 15.064 & .000 \\
\hline & $\begin{array}{l}\text { Family } \\
\text { Structure } \\
\end{array}$ & .028 & .011 & .084 & 2.662 & .008 \\
\hline & Family Support & -.041 & .007 & -.220 & -6.191 & .000 \\
\hline & Monitoring & -.052 & .010 & -.177 & -5.314 & .000 \\
\hline & Staff Support & -.007 & .006 & -.042 & -1.243 & .214 \\
\hline & Program Fit & -.020 & .010 & -.061 & -1.920 & .055 \\
\hline & Program Use & -.014 & .008 & -.054 & -1.682 & .093 \\
\hline
\end{tabular}


Research Question 2: In What Ways do Family Connections and Center Involvement Work in Conjunction with and Independent of One Another to Predict Youth Adjustment?

A second approach to data analysis was developed to examine the degree to which family connections and center involvement independently and interactively predict youth adjustment. For this analysis, a composite "family connections" variable was created by multiplying together the family support and parental monitoring scales. The resulting scores on this composite measure represented a continuum with youth reporting the lowest levels of monitoring and support at one end, and youth reporting the highest levels of monitoring and support at the opposite end. A decision was made not to create a second composite measure of center involvement, due to the lower inter-correlations among center variables.

The relative contributions of family connections and neighborhood youth center involvement to youth adjustment were then explored via regression analyses. A series of five-step hierarchical multiple regression analyses were conducted to examine associations between family connection, youth center involvement variables, and indicators of youth adjustment while also examining potential family and center interactions. When internalizing problem behaviors was included as the dependent variable, both gender and race were again entered as covariates. When externalizing problem behaviors was entered as the dependent variable, family living arrangements was entered as a covariate.

Covariates were entered first into the regression equations, followed by the family connections composite variable, and youth center involvement variables (i.e., staff support, center fit, center use). All possible two-way interactions involving the family connections variable were entered on the third step (e.g., family connections $x$ staff support). The fourth and fifth steps involved all possible three- and four-way interaction terms involving the low and high family connections groups.

Variables are said to interact in their accounting for variance in a criterion variable when they have a joint effect, which is over and above any additive combination of their separate effects (Cohen \& Cohen, 1983). In order to minimize the possibility of multicollinearity, given that the interaction terms are derived from the cross product of the predictor variables, the interaction terms were created using "centered variables." This transformation is one of the primary ways of reducing multicollinearity because of the highly correlated nature of interaction terms with the corresponding independent predictors (Norusis, 2006).

Internalizing problem behaviors. The results indicated that $8.6 \%$ of the variance in the internalizing scale was accounted for by the set of predictor variables $(F(4,913)=15.2$; $p<.001)$. The composite indicator of family connections was significantly associated with reported levels of internalizing problem behaviors $(B=-.24 ; p<.001)$. The only other main effect that emerged in the analysis was program use $(B=-.09 ; p<.007)$. Interestingly, no interaction terms were found to be statistically significant.

Externalizing problem behaviors. Ten-and-a-half percent of the variance in the externalizing measure was accounted for by the set of predictor variables $(\mathrm{F}(4,884)=28.6 ; p<.001)$. Again, the composite indicator of family connections was significantly associated with reported levels of externalizing problem behaviors $(B=-.31 ; p<.001)$. The only other main effect variable that emerged from these analyses was program fit $(B=-.06 ; p<.004)$, though program use did approach statistical significance $(B=-.05 ; p<.09)$. Again, no interaction terms were found to be statistically significant. 
The absence of significant interaction terms for the analyses on both the internalizing and externalizing measures suggests that center involvement does not buffer negative effects of low family connections on adolescent adjustment and that strong family connections do not compensate for limited involvement in neighborhood youth centers.

\section{Discussion}

The overall goal of the study was to develop a better understanding of the supportive role family relationships and neighborhood youth centers can have in the lives of urban, poor, minority youth living in what is generally considered to be high risk environments. As previous research has suggested, family characteristics and neighborhood youth centers are external assets or social contexts that promote positive youth development. The primary goals of the present study were to assess whether positive connections with family and neighborhood youth centers were independently associated with young people's positive adjustment. We also were interested in determining which of these two supportive contexts was most predictive of youth adjustment and whether a strong emotional connection with one setting was sufficient to compensate for a poor emotional connection with the other.

This sample of minority youth provided an opportunity to look at the growth and development of youth who live under adverse conditions in 25 stressed and challenged inner-city neighborhoods. The majority of the youth in this study appear to be characterized by relatively high levels of psychosocial adjustment. Overall, these youth tend to have families who are closely involved with them. They are generally highly monitored by their families and spend after school hours in supervised youth development programs. In addition to having scores that indicate positive youth adjustment, the majority of the youth evidenced other protective or resilient qualities such as good grades in school, involvement in school and extra curricular activities.

The results of the study are largely consistent with the hypotheses. Specifically, there is ample evidence that family connections are associated with youth adjustment, both in terms of internalizing problem behaviors and externalizing problem behaviors. Additionally, regression analyses indicated that center use, or the frequency of youth participation in center activities, was associated with fewer internalizing problem behaviors. Program fit, a measure of youth's satisfaction with center programs was a significant predictor of externalizing problem behaviors. However, family support was a consistently stronger predictor of youth adjustment than were youth center variables.

The absence of significant interaction terms between family and center variables also indicates that the effects of family and center are largely independent of one another. That is, a high level of involvement and support in one setting does not compensate for a low level of involvement or support in the other. This finding is significant in that it has been suggested that neighborhood centers might play an ameliorative role among youth who experience poor relationships with parents and other family members (Roffman, et al., 2001). Although youth centers can be a positive resource for inner-city youth and may, in fact, facilitate their psychological adjustment, they do not appear to compensate for the level of support that youth receive in their own families. Despite the positive role neighborhood centers play, the family appears to be the more powerful predictor of adjustment for youth living in the inner-city neighborhoods studied here. 
It is interesting to note, in addition, that youth adjustment within this context was connected to factors other than family and neighborhood center supports. For example, we found that internalizing problem behaviors were related to gender and race. Our findings are consistent with previous studies that have found higher rates of depression and anxiety in adolescent females than males. This difference is generally attributed to the tendency for males to externalize their emotional distress through active behaviors such as aggression whereas females are more likely to direct their emotional distress inward to the self (e.g. Kubik, Lytle, Birnbaum, Murray, Perry, 2003).

Our results also supported previous studies that identified higher rates of internalizing symptoms among Hispanic youth compared to African American and European American youth, (e.g. Pina \& Silverman, 2004; Varela, Vernberg, Sanchez-Sosa, Riveros, Mitchell, \& Mashunkashey, 2004; Varela, Weems, Berman, Hensley, \& Rodriquez de Bermal, 2007). Some evidence also has suggested that Hispanic females are the most vulnerable group for symptoms of depression and anxiety (McLaughlin, Hilt, \& Nolen-Hoeksema, 2007). However, the reasons Hispanic youth may be at more risk for internalizing symptoms have not been well-studied. Some have suggested that a possible source of anxiety is acculturation stress which may be greater for Hispanic youth and families who may have immigrated more recently to the United States (Canino, 2004; Cooley \& Boyce, 2004). Another explanation is that among Hispanic/Latino families it is common for parents to exert a controlling parenting style that includes demanding the child's acceptance of parent's assertions and beliefs, and foreclosure of discussion when differences arise. This parenting style has been associated with increased anxiety in the child (Varela et al., 2004). A final explanation is that mental health problems carry a heavy negative stigma in the Latino culture which may lead to adolescents being more likely to internalize emotional distress rather than express it more openly (Varela et al., 2007).

Externalizing problem behaviors were found to be significantly associated with family living arrangements, a finding that also supported previous research findings (Cleveland, 2003). Youth residing with both biological parents reported consistently fewer aggressive and delinquent behaviors in contrast to youth living in other settings such as single-parent, remarried, or other types of households. Numerous studies have found that youth residing in single parent families are prone to higher degrees of aggression, less social and academic competence, and lower levels of behavioral control in contrast to children living in two-parent households (Griffin et al., 1999; Hay et al., 2007; Pabon, 1998; Svensson, 2000). These findings have been attributed less to the processes of divorce than to the degree and context of parental conflict to which the youth has been exposed.

Overall, these findings highlight the importance of examining the broader context within with youth development occurs. Clearly, the family, and particularly parents active involvement with their children, is a significant factor in promoting adolescents' adjustment. Although neighborhood youth centers cannot compensate for the role played by the family, they too have been shown to play an important role in fostering youth adjustment. It is also clear that other factors such as gender, ethnicity, and the child's family living arrangements play critical roles in determining the development of youth living in urban, high-risk settings.

\section{Implications for Research, Practice, and Policy}

This study offers some interesting insights in terms of the positive youth development literature. First, the majority of minority youth who participated in the neighborhood youth centers studied were functioning well. That is, none of the adjustment scale scores of the Youth Self Report were close to the clinical cutoff norms established by Achenbach (Achenbach, 1991; Achenbach, 
Dumenci, \& Rescorla, 2003). This adds support to a small literature base (e.g., Li, et al., 2007) that has begun to examine factors of adolescents' resilience in poor, minority, urban neighborhoods.

Second, the importance of family involvement in predicting positive youth outcomes suggests that greater attention may need to be given to family factors within the positive youth development framework. Youth program planners may want to pay more attention to youth participants' levels of family involvement and consider having strategies in place for dealing with the absence of family and parental involvement. This has important implications in several areas such as program planning, staff training, and program evaluation. Additionally, it appears to remain conscious of the different ways that race and gender are considered in relation to program planning,

\section{Limitations and Future Directions}

There are limitations associated with the present study. Although the sample was large and the results are interesting, the study was exploratory and descriptive in nature. Because the study was first designed as an evaluation of neighborhood youth centers, the measures employed in the study were limited in terms of both their breadth and depth. A one time survey provided "snapshot" information of youth in these programs. In the future, research is needed that more rigorously attempts to assess precisely how much and in what ways youth use these neighborhood programs and how family and youth center contexts interact with other relevant contextual factors such as peer relationships, schools, neighborhood conditions, or availability of other community resources. In addition, the cross-section of youth involved in such studies should be studied over time, and compared to other urban youth who are not involved in youth center programs. Again, future research using a repeated measures design and making use of a control group would begin to address the contextual factors shaping the development and adjustment of urban, poor, minority youth.

These limitations aside, the study offers insight into the lives of minority youth residing in what is typically considered high-risk environments. The youth within this study evidenced fairly high levels of adjustment and were, for the most part, positively connected to their families. The findings of the study support the conclusion, as would be expected, that the families play an important role in influencing the development of the youth residing in high risk environments. It is clear, as well, that neighborhood youth centers can help shield minority and poor youth from the risks present in urban environments.

\section{References}

Achenbach, T. (1991). The Manual for the Youth Self Report. Burlington, VT: University of Vermont Press.

Achenbach, T.M., Dumenci, L., \& Rescorla, L.A. (2003). Are American children's problems still getting worse? A 23-year comparison. Journal of Abnormal Child Psychology, 31, 1-11.

Ary, D.V., Duncan T.E., Duncan, S.C., \& Hops, H. (1999). Adolescent problem behavior: The influence of parents and peers. Behaviour Research and Therapy, 37, 217-230.

Benson, P.L. (2002). Adolescent development in social and community context: A program of research. In R.M. Lerner, C.S. Taylor, \& A. von Eye (Eds.), Pathways to positive development among diverse youth (pp. 123-147). San Francisco, CA: Jossey-Bass. 
Canino, G. (2004). Are somatic symptoms and related stress more prevalent in Hispanic/Latino youth? Some methodological considerations. Journal of Clinical Child and Adolescent Psychology, 33, 272-275.

Canty-Mitchell, J.A., \& Zimet, G.S. (2000). Psychometric properties of the multidimensional scale of perceived social support in urban adolescents. American Journal of Community psychology, 28, 391-420.

Catalano, R.F., Berglund, M.L., \& Ryan, J.A. (2002). Positive Youth Development in the United States: Research findings on evaluations of Positive Youth Development programs. Seattle, WA: University of Washington, Social Development Research Group.

Cleveland, H.H. (2003). Disadvantaged neighborhoods and adolescent aggression: Behavioral genetic evidence of contextual effects. Journal of Research in Adolescence, 13, 211-238.

Cohen, J., \& Cohen, P. (1983). Applied multiple regression/correlational analysis for the behavioral sciences. Hillsdale, NJ: Lawrence Erlbaum.

Connell, J., Gambone, M.A., \& Smith, T. (2000). Youth development: Issues, challenges and directions. Philadelphia, PA: Public/Private Ventures.

Cooley, M.R., \& Boyce, C.A. (2004). An introduction to assessing anxiety in child and adolescent multiethnic populations: Challenges and opportunities for enhancing knowledge and practice. Journal of Clinical Child and Adolescent Psychology, 33, 210-215.

Dahlem, N.W., Zimet, G.D., \& Walker, R.R. (1991). The Multidimensional Scale of Perceived Social Support: A confirmation study. Journal of Clinical Psychology, 47, 756-761.

Dryfoos, J.G. (1990). Adolescents at risk: Prevalence and prevention. New York, NY: Oxford Press.

Eccles, J., \& Gootman, J. (2002). Community programs to promote youth development. Committee on Community-Level Programs for Youth. Board on Children, Youth, and Families, Commission on Behavioral and Social Sciences Education, National Research Council and Institute of Medicine. Washington, DC: Sage Publications.

Field, T., Diego, M., \& Sanders, C. (2002). Adolescents' parent and peer relationships. Adolescence, 3, 121-130.

Griffin, K.W., Scheier, L.M., Botvin, G., Diaz, T., \& Miller, N. (1999). Interpersonal aggression in urban minority youth: Mediators of perceived neighborhood, peer, and parental influences. Journal of Community Psychology, 27, 281 - 298.

Hay, C., Fortson, E.N., Hollist, D.R., Altheimer, I., \& Schaible, L.M. (2007). Compounded risk: The implications for delinquency of coming from a poor family that lives in a poor neighborhood. Journal of Youth \& Adolescence, 36, 593-605.

Halpern, R. (2005). Instrumental relationships: A potential model for inner-city youth programs. Journal of Community Psychology, 33, 11-20. 
Hirsch, B.J. (2005). A place to call home. Washington, DC: APA Press.

Hirsch, B.J., Roffman, J.G., Deutsch, N.L., \& Pagano, J. (2000). Inner-city youth development organizations: Strengthening programs for adolescent girls. Journal of Early Adolescence, 20, 210-230.

Ingoldsby, E.M., Shaw, D.S., Winslow, E., Schonberg, M., Gilliom, M., \& Criss, M.M. (2006). Neighborhood disadvantage, parent-child conflict, neighborhood peer relationships, and early antisocial behavior problem trajectories. Journal of Abnormal Child Psychology, 34, 303-319.

Kubik, M.Y., Lytle, L.A., Birnbaum, A.S., Murray, D M., \& Perry, C.L. (2003). Prevalence and correlates of depressive symptoms in young adolescents. American Journal of Health Behavior, $27,546-553$.

Larson, R.W. (2000). Toward a psychology of positive youth development. American Psychologist 55, 170-183.

Lerner, R.M., Lerner, J.V., Almerigi, J., Theokas, C., Phelps, E., Gestsdottir, S., et al. (2005). Positive youth development, participation in community youth development programs, and community contributions of fifth grade adolescents: Findings from the first wave of the 4-H Study of Positive Youth Development. Journal of Early Adolescence, 25(1), 17-71.

Lerner, R.M. (2004). Liberty: Thriving and civic engagement among America's youth. Thousand Oaks, CA: Sage.

Lerner, R.M., Fisher, C.B., \& Weinberg, R.A. (2000). Toward a science for and of the people: Promoting civil society through the application of developmental science. Child Development, 71, 11-20.

Li, S.T., Nussbaum, K.M., \& Richards, M.H. (2007). Risk and protective factors for urban African-American youth. American Journal of Community Psychology, 39, 21-35.

Loder, T.L., \& Hirsch, B.J. (2003). Inner-city youth development organizations: The salience of peer ties among early adolescent girls. Applied Developmental Science, 7, 2-12.

Masten, S.A. (2001). Ordinary magic: Resilience processes in development. American Psychologist, 56, 227-238.

McCreary, M.L., Slavin, L.A., \& Berry, E.J. (1996). Predicting problem behavior and self-esteem among African American adolescents. Journal of Adolescent Research, 11, 216-234.

McLaughlin, K.A., Hilt, L.M., \& Nolen-Hoeksema, S. (2007). Racial/ethnic differences in internalizing and externalizing symptoms in adolescents. Journal of Abnormal Child Psychology, $35,801-816$.

Morrissey, K.M., \& Werner-Wilson, R.J. (2005). The relationship between out of school activities and positive youth development: An investigation of the influences of communities and family. Adolescence, 40 67-85. 
Noam, G.G., \& Fiore, N. (2004). Relationships across multiple settings: An overerview. New Directions for Youth Development, 103 (Fall), 9-16.

Norusis, M.J. (2006). SPSS 14.0 statistical procedures companion. Englewood, NJ: Prentice Hall.

Pabon, E. (1998). Hispanic adolescent delinquency and the family: A discussion of sociocultural influences. Adolescence, 33, 941-955.

Parker, J., \& Benson, M.J. (2004). Parental support and monitoring and adolescent functioning. Journal of Adolescent Psychology, 39, 519-530.

Perkins, D.F., \& Borden, L.M. (2003). Positive behaviors, problem behaviors, and resiliency in adolescence. In R.M. Lerner, M.A. Easterbrooks, \& F. Mistry (Eds.), Handbook of psychology (pp. 373-394). Hoboken, NJ: Wiley Publishing.

Pina, A., \& Silverman, W.K. (2004). Clinical phenomenology, somatic symptoms, and distress in Hispanic/ Latino and European American youths with anxiety disorders. Journal of Clinical Child and Adolescent Psychology, 33, 227-236.

Prelow, H.M., Weaver, S.R., \& Swenson, R.R. (2006). Competence, self-esteem, and coping efficacy as mediators of ecological risk and depressive symptoms in urban African American and European American youth. Journal of Youth \& Adolescence, 35, 507-517.

Rhodes, J.E. (2004). The critical ingredient: Caring youth-staff relationships in afterschool settings. New Directions for Youth Development, 101, 145-161.

Roffman, J.G., Pagano, M.E., \& Hirsch, B.J. (2001). Youth functioning and the experiences of inner-city after-school programs among age, gender, and race groups. Journal of Child and Family Studies, 10, 85-100.

Rohner, R.P., \& Britner, P.A. (2002). Worldwide mental health correlates of parental acceptance-rejection: Review of cross-cultural and intra cultural evidence. Cross-Cultural Research: The Journal of Comparative Social Science, 36, 15-47.

Roth, J.L., \& Brooks-Gunn, J.B.(1993).Positive youth development: Thriving as the basis of personhood and civil society. Journal of Adolescent Health, 32,221-234.

Scales, P.C., Benson, P.L., Leffert, N., \& Blyth, D.A. (2000). Contribution of developmental assets to the prediction of thriving among adolescents. Applied Developmental Science, 27, 2738.

Smith, C., \& Krohn, M.D. (1995). Delinquency and family life among male adolescents: The role of ethnicity. Journal of Youth and Adolescence, 24, 69-93

Svensson, R. (2000). Risk factors for different dimensions of adolescent drug use. Journal of Child \& Adolescent Substance Abuse, 9, 67-90.

Taylor, R.D. (1996). Adolescents' perceptions of kinship support and family management practices: Association with adolescent adjustment in African American families. Developmental Psychology, 32, 687-695. 
Theokas, C., \& Lerner, R.M. (2006). Observed ecological assets in families, schools, and neighborhoods: conceptualization, measurement, and relations with positive and negative developmental outcomes. Applied Developmental Science, 10, 61-74.

Varela, R.E., Vernberg, E.M., Sanchez-Sosa, J.J., Riveros, A., Mitchell, M., \& Mashunkashey, J. (2004). Anxiety reporting and culturally associated interpretation biases and cognitive schemas: A comparison of Mexican, Mexican-American, and European-American families. Journal of Clinical Child and Adolescent Psychology, 33, 237-247.

Varela, R.E., Weems, C.F., Berman, L.H., \& Rodriquez de Bernal, M.C. (2007). Internalizing symptoms in Latinos: The role of anxiety sensitivity. Journal of Youth and Adolescence, 36, 429-440.

Voydanoff, P., \& Donnelly, B.P. (1999). Risk and protective factors for psychological adjustment and grades among adolescents. Journal of Family Issues, 20, 328-349.

Walker, J., Marczak, M. Blyth, D., \& Borden, L. (2005). Designing youth development programs: Toward a theory of developmental intentionality. In J.L. Mahoney, R.W. Larson, \& J.S. Eccles (Eds.), Organized activities as contexts of development (pp. 399-418). Mahwah, NJ: Lawrence Erlbaum Associates.

Werner, E.E., \& Smith, R.S. (2001). Journeys from childhood to midlife: Risk, resilience and recovery. Ithaca, NY: Cornell University Press.

Wynne, E.A. (1997). For character education. In A. Molnar (Ed.), The construction of children's character. Chicago, IL, US: The National Society for the Study of Education.

Yohalem, N., Pittman, K., \& Wilson-Ahlstrom, A. (2004). Getting into the black box: Measuring quality of positive youth development programs. The Harvard Evaluation Exchange, 10, 6-9.

Zimmerman, M.A., Ramirez-Valles, J., Zapert, K.M., \& Maton, K.I. (2000). A longitudinal study of stress-buffering effects for urban African American male adolescent problem behaviors and mental health. Journal of Community Psychology, 28, 17-33.

Acknowledgments: This research was supported by funding from the State of Connecticut, Office of Policy and Management. The authors wish to thank Valerie A. LaMotte, Office of Policy and Management, for her assistance with this research, and the staff and youth at participating Neighborhood Youth Centers.

(C) Copyright of Journal of Youth Development Bridging Research and Practice. Content may not be copied or emailed to multiple sites or posted to a listserv without copyright holder's express written permission. However, users may print, download or email articles for individual use. 